\title{
LI-CHI CHEN
}

Uniwersytet Kazimierza Wielkiego w Bydgoszczy, Polska https://orcid.org/0000-0002-3167-3959

\section{ANNA SROKA-GRĄDZIEL}

Uniwersytet Kazimierza Wielkiego w Bydgoszczy, Polska https://orcid.org/0000-0001-8160-2625

\section{FU-LAN LEE}

Uniwersytet im. Adama Mickiewicza w Poznaniu, Polska https://orcid.org/0000-0003-2408-3384

\section{ERYK HAJNDRYCH}

Uniwersytet Kazimierza Wielkiego w Bydgoszczy,

\section{Polska}

https://orcid.org/0000-0002-8961-4177

Copyright and License: Copyright by Instytut Języka Polskiego PAN, Kraków 2021. This article is published under the terms of the Creative Commons Attribution - NoDerivatives 4.0 International (CC BY- ND 4.0) License (https:// creativecommons.org/licenses/by-nd/4.0/legalcode.pl).

\section{WIT AND HUMOR IN CHINESE CHARACTERS: A SOCIO-CULTURAL AND HISTORICAL PERSPECTIVE}

Keyw ords: Chinese characters, Chinese ligatures, homophonic puns, human behavior, humor.

\begin{abstract}
Building on Bergson's ([1911] 2014) account of laughter, as well as two recognized functions of Chinese humor - 寓教於樂 ‘wrapping instructions in entertainment/amusement' (Liao 2001) and 會心微笑 'a hearty laugh or a knowing smile' (Chen 2017) - this study intends to analyze the wit and humor found in Chinese characters from a socio-cultural and historical perspective. The data used in this analysis come from internet resources and books, as well as from the authors' linguistic repertoire. We have observed six sources of humor in Chinese characters. These are: (a) the visual form of a Chinese character; (b) decomposing a Chinese character; (c) Chinese ligatures; (d) Chinese homophonic puns; (e) misreading of similar Chinese characters; and (f) the borrowing of Japanese kanji. Our findings suggest that funny Chinese characters should contain human behavioral attributes and wrapped instructions and will evoke a hearty laugh or knowing smile from the in-group members of a Chinese-speaking community.
\end{abstract}




\section{INTRODUCTION}

Chinese characters are logograms used in writing, not just in Chinese, but also in Japanese, Korean, and, formerly, Vietnamese. Although no one knows exactly when Chinese characters emerged, there are two legends regarding their origin (see Shi and Luo 2013; Wei 2014). According to one legend, Chinese characters derived from the Eight Trigrams created by $\mathrm{Fu} \mathrm{Xi}$, the first of the Three Sovereigns of ancient China. According to the second legend, an ancient historian named Cang Jie had four eyes and four pupils and was able to observe the various things of the world. He was inspired to create symbols that represented objects, creatures, and affairs according to their forms and structures, forming the oldest Chinese characters.

Each of these two legends has its own unique explanation and conveys Chinese wisdom and cultural significance; however, Chinese characters may look mysterious to the eyes of Westerners. According to Rusk (2007, 69-70), the cryptographer Blaise de Vigenère (1523-1596 AD) regarded Chinese (and Japanese) characters as hieroglyphs and associated them with "the semihuman creatures of Mediterranean myth". The mythology encoded in Chinese characters perhaps results from the fact that characters are constructed differently to alphabets. Indeed, Chinese characters have their own methods of formation. According to 說文解字 'Explaining and Analyzing Chinese Characters', the first and oldest comprehensive dictionary of Chinese characters authored by Xu Shen (58-148 AD), there are six categories of Chinese characters: 象形 'pictographic characters'; 指事 'selfexplanatory characters’; 會意 'associative compounds'; 形聲 ‘pictophonetic characters'; 轉注 'derived characters'; and 假借 ‘borrowed characters' (Shi and Luo 2013; Zhou 2014).

Due to the structural composition and use of Chinese characters, as well as the sociocultural and historical values they convey, we believe that Chinese characters also have humor encoded in them. Although humor has long been an intriguing topic for different academic disciplines, particularly the fields of linguistics, anthropology, psychology, and cultural and gender studies, many previous studies on Chinese humor have exclusively focused on areas such as ancient Chinese jokes, the Chinese perception of humor, definitions of Chinese humor, the historical development of Chinese humor, and conversational humor in Chinese-speaking societies (G.-J. Chen 1985; Tong 1999; Liao 2001, 2003a, 2003b, 2003c; Huang 2009; Yue 2010; L.-C. Chen 2017). More specifically, not much ink has been spent on discussing the innate wit and humor found in Chinese characters. As such, this study seeks to explore the wit and humor encoded in them.

\section{THE FUNCTIONS OF HUMOR IN CHINESE CHARACTERS}

According to Bergson ([1911] 2014), people will not laugh at a landscape, but they may be entertained by an animal because they can observe human behavioral attributes. Similarly, when we feel that certain Chinese characters look or sound funny, it may be because they express human behavioral attributes with which we are familiar. Liao (2001) has also proposed the social theory of 寓教於樂 'wrapping instructions in 
entertainment/amusement' as a means of understanding traditional Chinese humor. Humor in Chinese characters can be regarded as a specifically Chinese form of humor, and it is thus reasonable to argue that the humor in Chinese characters contains instructional functions. More specifically, we laugh at certain Chinese characters not only because they amuse us due to their forms, shapes, or the sounds of their pronunciation, but also because they contain wit. L.-C. Chen (2017) has further argued that modern Taiwanese humor evokes 會心微笑 'a hearty laugh or a knowing smile' among in-group members of Taiwanese society, being constructed on shared in-group knowledge of this society. In Chen's perspective, the humor in Chinese characters has the same entertaining function and can be used to reinforce in-group solidarity among members of a Chinese-speaking community. To conclude, funny Chinese characters, we may say, resemble human behavioral attributes, wrapped instructions, and evoke a hearty laugh or a knowing smile from the in-group members of a Chinese-speaking community.

\section{ANALYSIS}

\subsection{Source 1: The visual form of a Chinese character}

The humor encoded in Chinese characters mainly comes from their forms. Using and playing with some of the structural features of certain Chinese characters (such as transforming, adding, or removing strokes or radicals) can be seen as a way of expressing humorous information.

(1)

a) 小三 'little-three'; 'mistress'

b) 小王 'little-king'; 'lover'

As (1) shows, 小三 is a Chinese neologism used to refer to one's mistress. Its male counterpart, 小王, is known to have derived from it, and the vertical stroke added to 三 symbolizes the male sex organ. Interestingly, the character 王 is a common Chinese surname, which can be prefixed by 小 'little' to produce an affectionate diminutive nickname. More specifically, 小王 can be used to refer to a friend whose surname is 王. The ambiguous nature of 小王 has further reinforced its comical nature.

The following example shows how humor is encoded in the visual form of a character.
a) 圆
b) 闪
c) 冏 $\mathrm{rz}$

In its original meaning, 圆 refers to bright and light. However, as can be seen in (2a), due to its apparent similarity to a negative facial expression (with an open mouth and intense 
frown), it is widely used as an internet emoticon to demonstrate astonishment or awkwardness. As mentioned by Zhao (2014), the present meaning of 圆 may refer to such emotions as gloomy, awkward, helpless, sorrowful, confused, and embarrassed. Zhao also underlines its intercultural universality as it is possible for non-Chinese language speakers to understand its meaning solely from the character's visual form. Interestingly, this character may also be replaced by another character, 冏, as in (2b). This character contains a vertical stroke with a hook $J$ at the end, resembling a hair curl. On the internet, we can also find a version with "rz" following the character - these two letters represent arms and legs. As such, the whole image refers to a person who has suffered failure or despair, as shown in $(2 \mathrm{c})$.

More examples are found in the form of funny dialogue jokes between two personified Chinese characters, as shown in (3).

(3) 巾 talks to 币, “Dear son, as you put the doctoral hat on, your value has increased".

In (3), 币 is a simplified form of 幣, which literally means 'money'. A left-falling stroke is added to 巾 not only to symbolize a doctoral hat, but also to show increased value. This example also outlines some cultural factors and can be considered to reflect the importance Chinese people attach to higher education. This correlates favorably with Yu's (2014) statement that dialogue jokes between two Chinese characters may concern almost every aspect of Chinese society, including education, ethics, morals, politics, marriage, family, and more.

\subsection{Source 2: Decomposing a Chinese character}

This type of humor decomposes a character into its constituent parts, with these parts treated as individual characters. However, the constituent components of a Chinese character are not necessarily characters in their own right. When it can be broken into individual characters, such a coincidence brings about a hearty laugh or a knowing smile. As over $80 \%$ of modern Chinese characters are compound characters consisting of a semantic radical and a phonetic component (Hoosain 1991; Williams and Bever 2010), if they have negative semantics, many of them can be decomposed for use in conversation as euphemisms.

(4)

a) 具戈戈

賻 'scabby, cheap'

b) 米田共

糞 'excrement'

As can be seen in (4), a speaker can use 貝戈戈 to refer to the single Chinese character 賤 'scabby, cheap' and 米田共 to refer to 粪 'excrement'. Thus, they can avoid using these two characters and, at the same time, create a humorous effect. 
The method of decomposition can also be applied to rarely used characters. If a person does not know how a rarely used character is pronounced or such a sign does not exist in the computer program or web browser they are using, they can break the character down into its parts and use these elements in its place. This can be a temporary way of presenting these characters while using a computer before learning the correct pronunciation. The following gives an example of two names with rarely used characters.

(5)

a) 陶喆 ‘Tao Zee’ (name of a Taiwanese singer)

陶吉吉

b) 游錫衤 'You Si-Kun' (name of a Taiwanese politician) 游錫方方土

When the Taiwanese singer 陶喆 started his career, his given name 喆 was decomposed into two characters 吉吉 in online discussions because many people did not know how to pronounce it. Another example is 游錫妿, a Taiwanese politician. His given name 妿 is a rarely used character, thus people who do not know how to type it phonetically will type 方方土 instead. Later on, people used 陶吉吉 (instead of 陶喆) and 游錫方方土 (instead of 游錫枋) as their nicknames. Moreover, as three-character names are more common than two-character names in Taiwan, 陶吉吉 looks like a real name because it contains three characters. Yet 吉吉 and 方方土 do not mean anything, and the characters are actually absurd in terms of a person's name. This incongruity creates humor when they are used as nicknames (Oring 2003).

Another phenomenon was formed according to the features of the bulletin board system (BBS), which works like a forum in Taiwan. A user can choose to reply, like on a forum, or write a line right at the bottom of a post to make a comment. A user can only write one line of 80 digits at a time. In addition, users cannot change the size of words on BBS. As a result, if a user wishes to enlarge their words, they will break the characters into separate parts and type each part individually.

$\begin{array}{ll}\text { 零分 } & \rightarrow \begin{array}{c}\text { 雨八 } \\ \text { 令刀 }\end{array}\end{array} \rightarrow$ 雨八令刀

零分 'zero point'

雨八令刀 'rain, eight, order, and knife'

As can be seen in (6), by way of illustration, a user commenting 零分 'zero point' could break the characters into upper and bottom parts and put them in two lines so the comment will look bigger, like in the second column. This is a common practice on BBS: a user could just write 雨八令刀 'rain, eight, order, and knife' on the same line and other BBS users will understand and find this a typical way of typing humorous. 


\subsection{Source 3: Chinese ligatures}

Based on the reader's visual perception of a character's form, Chinese ligatures can also be a source of humor. This appears a lot in traditional expressions of blessing. As regards users of Chinese characters, ligatures challenge their knowledge about characters, including how large their vocabulary is and how well they can analyze character structures. It brings about satisfaction when people find hidden characters in a sign, and they appreciate the work of the creator. In addition, ligatures can be used as a modern way of engaging in mockery. People put some characters or radicals together to form another character; however, in this case people do not create a new character or a new sign. Instead, they find an existing character with the parts they wish to combine.

(7)

a) 馬英九 'Ma Ying-Jeou' (name of a Taiwanese politician)

陳水扁 'Chen Shui-Bian' (name of a Taiwanese politician)

騙 'to defraud'

b) 馬 'surname Ma'

皇 'emperor'

䮵 'a horse with white and yellow hair'

c) 共 'communism'

虫 'insect'

巷 'cricket' (used to indicate 'commie')

For instance, during the 2004 presidential election campaign in Taiwan, the two candidates were 馬英九 'Ma Ying-Jeou' and 陳水扁 'Chen Shui-Bian'. The most symbolic characters from the two candidates' names were 馬 and 扁. People put these two characters together to form 騙 'to defraud', implying that both candidates were lying. In this example, 馬 and 扁, the parts of 騙 and the character 騙 itself, semantically, all play a role in this game.

The other possibility is that people give a rarely used character new meaning based on its parts and ignore the real meaning of the character. To give an example, during the presidency of 馬英九 'Ma Ying-Jeou', people who wished to present President Ma as a dictator started using the character 騜 'a horse with white and yellow hair', which includes the president's surname 馬 and the character 皇 'emperor'. As a result, 騜 lost its original meaning and came to refer to the 'emperor-like President Ma'.

Another similar way of showing disrespect is to add a radical. For instance, opponents of the Chinese Communist Party use the character 蛬 'cricket' to refer to communists. This character is a combination of 共, the abbreviation of 共產 'communism', and 虫 'insect'. The new use of 蛬 'cricket' ignores its real meaning and instead indicates 'commie'. With regard to aggression, both the decomposition and ligature of a Chinese character divert the attention of the listener so that an aggressive thought may be more safely expressed (Oring 2003). 


\subsection{Source 4: Chinese homophonic puns}

According to Fong (2000), Chinese people traditionally desire to ensure that good luck accompanies their families during Lunar New Year, and luck talk is believed to help achieve this purpose. As Fong further observed from her Hong Kongese and Taiwanese interview data, part of this Lunar New Year luck talk is bound up with food and includes Chinese words for food and prosperity food rhymes. More specifically, her data show that these two categories of speech acts are based on homophonic puns. Interestingly, many Chinese neologisms based on homophonic puns have also been created in Chinese-speaking societies, which not only reflect a changing society, but also create humor that triggers a knowing smile from the in-group members of the Chinesespeaking community. This is highlighted in the two neologisms created in China during the 2000s: 河蟹 ‘river crab' and 草泥马 'grass-mud horse; alpaca'. 河蟹 (hé-xiè) is a homophonic pun of 和谐 (hé-xié), which comes from and frequently appears on the internet in China. This neologism is used in reference to the Chinese government's official policy for a harmonious society and the associated policy of internet censorship. As Tang and Yang $(2011,680)$ point out:

In 2004, Chinese authorities envisaged and called the whole nation to come together to construct "a socialist harmonious society", presumably one in which there is no social conflict or dissent. Soon after, not inappropriately, internet users twisted the word "harmony" to humorously insinuate government censorship, control and suppression; and whenever online postings or blogs voicing dissent disappear, internet users know that they have been "harmonized off". "River crab" in this song is thus code for the authorities" "harmonization".

This neologism is now used to refer to one's online postings being "harmonized off", as manifested in the following example:

(8) 藝人梁詠琪（Gigi)）的個人微博慘被「河蟹」。梁詠琪昨日在內地個人微博轉 貼毒奶粉案維權爸爸趙連海被無理控告的報道, 旋即被要求將文章刪除 (WWW1).

'Gigi Leung, an entertainer, with a Weibo [Chinese microblogging website] that has been "harmonized off". Yesterday, Gigi Leung reposted news on Weibo about Lianhai Zhao being unreasonably accused, he is an activist for parents of children harmed during the Chinese milk scandal. This repost was soon asked to be removed.'

On the other hand, 草泥马 (căo-ní-mă) is used as a euphemism for the curse phrase 苓你妈/操你妈 (cào-nĭ-mā) 'fuck your mother', 'fuck you' to circumvent censorship, which is also a homophonic pun. This neologism first appeared as one of the 10 mythical creatures created in a hoax article on Baidu Baike in early 2009 (WWW2). According to Yang (2017), Baidu WoW bar, which morphed from an online forum for World of Warcraft gamers into a venue for socialization among male netizens, is known for this kind of internet satire. The New York Times also argued that this neologism was conceived as an impish protest against the Chinese government's strict censorship, due to the fact 
that the foul-named little horse makes the censors look ridiculous (WWW3). As argued by Tang and Yang $(2011,687)$, the grass-mud horse can be regarded "as a social text to which meanings are ascribed through the surrounding discursive practices, which relates further to the wider social-cultural contexts".

Truly, language can be used to mark history. The two neologisms 河蟹 and 草泥马 further revealed the socio-political situation of China during the 2000s. As Algeo $(1991,1)$ has put it:

A community is known by the language it keeps, and its words chronicle the times. Every aspect of the life of a people is reflected in the words they use to talk about themselves and the world around them. As their world changes - through invention, discovery, revolution, evolution or personal transformation - so does their language. Like the growth rings of a tree, our vocabulary bears witness to our past.

Chinese people's creation of these two neologisms, as well as others, can be regarded as showing their dissatisfaction with government censorship, but in a safe manner, thanks to the "defensibility" of these newly popularized words. As different Chinese characters are used to add different meanings to the original sensitive phrases, they can later be denied or cancelled in certain contexts. Additionally, the two neologisms have become widespread in Chinese-speaking communities, in the sense that they are entertaining because of their sarcastic nature. This has also reflected Chinese people's playful attitudes towards the government's policy. Despite their frustration at not being able to halt or bypass government censorship, they can still entertain themselves by mocking government policy in a sarcastic, humorous, but also defensible manner.

\subsection{Source 5: Misreading of similar Chinese characters}

In data collected from Facebook posts, we observed that humor may come from a Facebook user's misreading of similar Chinese characters, especially when the posts are constructed in a misleading manner.

(9) (WWW4)

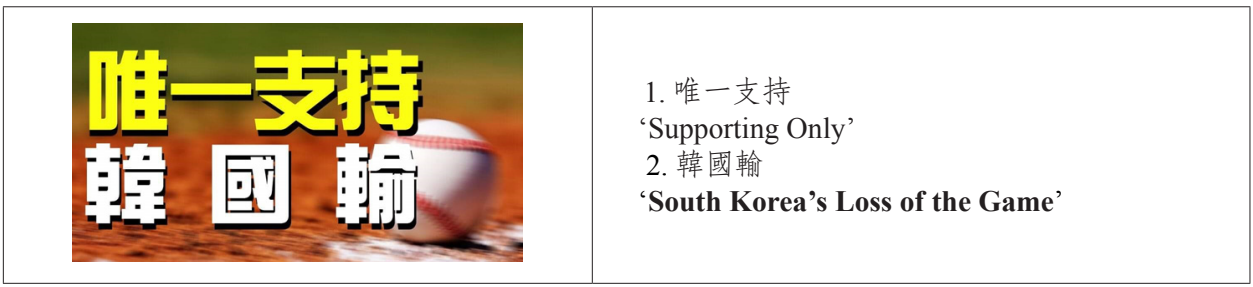

On November 12, 2019, Taiwan's national baseball team played the champion team South Korea and secured victory in the WBSC Premier12 championship, which served as a qualifying event for the 2020 Tokyo Olympics. As baseball games have always 
been popular in Taiwan, many Taiwanese people showed their support for their national baseball team on Facebook. However, as the above example shows, while support was given, it also offered an opportunity to tease Han Kuo-Yu (KMT's nominee for the 2020 Taiwan presidential election) and his fans. The humor is based on a misreading of the two Chinese characters 瑜 and 輸. While 韓國“瑜” is the name of this Taiwanese politician, 韓國“輸” literally means South Korea’s loss of the game (to Taiwan).

The text in the figure looks like a campaign slogan, as manifested in the verb 支持 'to support', which is used by Taiwanese political candidates to ask for support from voters. Additionally, the three characters 韓國輸 are placed in the second part of the text. More specifically, readers are led to construct a context into which the first part of the text fits. For example, at first glance the reader may perceive line 1 to be a political slogan. Line 2, as we can see, is used to ask for the support of "South Korea's loss of the game (to Taiwan)". The constructed context (i.e. like a campaign slogan) is eventually contradicted and may generate incongruity, which is the source of its humor (see Suls 1972, 1983; Shultz 1976). Additionally, the abrupt change of the proposition is unexpected and can also be regarded as garden-path humor (see Yamaguchi 1988; Dynel 2009) or as 無厘頭 'nonsense humor' (see L.-C. Chen 2016, 2017).

Readers may find the textual wit quite humorous in the sense that they are likely to be entertained by their own misreading of these two similar Chinese characters, which is caused by their holistic processing of the Chinese character 輸. Holistic processing is a behavioral visual expertise marker for recognizing faces and non-face objects. Gauthier and Tanaka (2002) argue that the components of the stimuli tend to be integrated and perceived as a whole, instead of as constituent parts, and thus one's flexibility in accessing the information of these individual parts is reduced (see Maurer, Le Grand and Mondloch 2002). On the other hand, a Chinese character is composed of strokes, which are combined into a square-shaped configuration. As both Chinese characters and faces have a homogenous shape, and can be recognized individually, Chinese character recognition is similar to face recognition (McCleery et al. 2008).

However, as argued by Liu et al. (2016), the holistic processing of Chinese characters can be influenced by one's prior experiences with similar object types. Their psychological experiments also showed that when readers trained to use simplified Chinese characters tried to read traditional Chinese characters, they tended to look for familiar components or parts of components within the traditional Chinese characters. Similarly, one may mistake 輸 for 瑜 if other textual or contextual clues are misleading, which is also a common source of humor on Facebook. Although the fans of Han Kuo-Yu probably do not find this post humorous, being sarcastic in nature, this post can provoke a hearty laugh or a knowing smile from those who are familiar with Han Kuo-Yu's campaign slogans. The wit is also wrapped in entertainment. 


\subsection{Source 6: The borrowing of Japanese kanji}

According to Hayashi $(2005,9-10)$, it was not until the $8^{\text {th }}$ century that Japanese people started to adopt logographic Chinese characters and apply them to the Japanese writing system. As Hayashi has further stated, Chinese characters first came to Japan on items imported from China. The earliest known instance of such an import was the golden seal of the King of Na given by the Emperor Guangwu of Han in 57 AD (this is a solid gold seal that was discovered on Shikanoshima Island in Fukuoka Prefecture). It is believed that the oldest objects with written inscriptions made in Japan include a mirror associated with Sumida Hachiman Shrine, dating from 443 AD or 503 AD, and a sword found in the Inariyama kofun in Saitama Prefecture, dating from 471 AD. After two hundred years, kanji started to appear in history books and works of literature, such as Kojiki 'Records of Ancient Matters', Nihonshoki 'Chronicles of Japan', and Manyoshu 'Collection of Ten Thousand Leaves'. Interestingly, while Japanese kanji came from Chinese characters, Chinese has many borrowed words from the Japanese language. These borrowed words, more specifically, kanji, can be found in everyday linguistic practice and can be a source of humor, as manifested in the following extract from an online entertainment news website.

(10)

王柏傑強暴蔡依林的橋段, 拍了4次即完成, 不過, 有眼尖網友發現, 指蔡依林 被壓床上掙扎時，臉上表情氣憤，但焦點卻全在她左手竟比了一個讚，是標準 的「口嫌體正直」(WWW5).

'The rape scene by Jacob Wang and Jolin Tsai was shot only four times, but sharp-eyed netizens found that while Jolin Tsai was pressed down into the bed, struggling with anger, her left hand gave a thumbs up, which has become the focus of attention. This is a typical example of "the mouth says no, but the body is honest"".

As (10) shows, 口嫌體正直 is composed of five Chinese characters. Despite the fact that this expression is neither a sentence nor a phrase, it is alone encoded with the meaning "despite the voiced denial, the body approves honestly". In fact, this expression comes from the Japanese expression: 口が嫌だといっても体は正直なものだ. As only the kanji in this phrase can be read by Chinese speakers, only the five kanji are borrowed and used in everyday linguistic practice. The borrowing of Japanese kanji into Chinese is due to the fact that the Japanese writing system is close to the Chinese one (Tang 1989). As Tang has further explained, this is due to the longstanding geographical, historical, cultural, and linguistic relationships between the two cultures and countries.

There are different categories of Japanese loanwords used in Taiwanese Mandarin from different periods of contact with Japan which can be used to examine the changing social structure of Taiwan (Hsieh and Hsu 2006). The use of 口嫌體正直 in Taiwanese everyday linguistic practice, we may say, reflects a sarcastic and critical attitude towards those who speak one way and think another, but in an indirect and implicit manner, 
since the combination of the five kanji does not construct any meaning. Because of this, while the sarcasm is shown humorously, which also helps to reinforce in-group solidarity, the humor is shared only by in-group members, including those who understand Japanese, or those who have heard of the expression and appreciate its humor. Indeed, as S.-F. Chen and L.-C. Chen (2012) have observed, Japanese loanwords that have been adapted to fit into the Chinese grammatical system can be used in a creative and humorous manner.

\section{CONCLUSION}

The main goal of the present study has been to analyze the phenomenon of wit and humor in Chinese characters from a socio-cultural and historical perspective. This research has shown that the humorous aspects of a Chinese character derive from several sources, such as its basic, unchanged visual form; its decomposition and misreading; a novel form created as a result of binding with other characters; references to homophonic puns; and its existence in other language systems. It seems that there are some primary criteria determining whether or not the character may be considered funny, i.e. whether it contains human behavioral attributes, wrapped instructions, and evokes a hearty laugh or a knowing smile from in-group members of a Chinesespeaking community. Triggering this reaction not only requires an individual to have linguistic knowledge of Chinese characters, but, in many cases, to also have a deep understanding of cultural and social connections between characters and reality, as well as being able to think abstractly and creatively. Further investigation in this field from other relevant perspectives would be a great help in discovering more representations of wit and humor in Chinese characters. Another possible dimension of future research would be the analysis of native and non-native speakers' perceptions of funny characters, which may vary depending on an individual's level of proficiency or cultural background.

\section{REFERENCES}

Algeo, J., ed. 1991. Fifty Years among the New Words: A Dictionary of Neologisms, 1941-1991. Cambridge: Cambridge University Press.

Bergson, H. [1911] 2014. Laughter: An Essay on the Meaning of the Comic. Mansfield Center, CT: Martino Publishing.

Chen, G.-J. 1985. Zhōngguó Güdài Xiàohuà Yánjiù [A Study of Ancient Chinese Jokes]. Taipei: National Taiwan Normal University MA Thesis.

Chen, L.-C. 2016. “A Socio-Pragmatic Analysis of Wúlitóu 'Nonsense' in Taiwanese Verbal Interactions". Lodz Papers in Pragmatics 12 (1): 53-76.

Chen, L.-C. 2017. Taiwanese and Polish Humor: A Socio-Pragmatic Analysis. Newcastle upon Tyne: Cambridge Scholars Publishing. 
Chen, S.-F., and L.-C. Chen. 2012. “'Ài Jiù Zhái Yìqǔl': Táiwān 'Zhái'-lèi Xīn Cíyǔ Tòushì” [“Love Is to Zhái Together!": A Study of the Neologism "Zhái” in Taiwan Mandarin]. The Journal of Chinese Sociolinguistics 16: 72-82.

Dynel, M. 2009. Humorous Garden-Paths: A Pragmatic-Cognitive Study. Newcastle upon Tyne: Cambridge Scholars Publishing.

Fong, M. 2000. “'Luck Talk' in Celebrating the Chinese New Year”. Journal of Pragmatics 32 (2): 219-237. Gauthier, I., and J.W. Tanaka. 2002. "Configural and Holistic Face Processing: The Whole Story”. Journal of Vision 2 (7): 616.

Hayashi, C. 2005. "Nihongo no Moji to Shoki”" [Characters and Writing in Japanese Language]. In Asakura Nihongo Kōza 2: Moji, Shoki [Asakura Lectures on Japanese Language 2: Characters and Writing], eds. Y. Kitahara and C. Hayashi. Tokyo: Asakura Shoten, 1-21.

Hoosain, R. 1991. Psycholinguistic Implications for Linguistic Relativity: A Case Study of Chinese. Hillsdale, NJ: Erlbaum.

Hsieh, S.C.-Y., and H.-L. Hsu. 2006. "Japan Mania and Japanese Loanwords in Taiwan Mandarin: Lexical Structure and Social Discourse". Journal of Chinese Linguistics 34 (1): 44-79.

Huang, C.-S. 2009. Jiěyí Biān: Zhōngguó Gǔdài Xiàohuà Zhuāntí Yánjiù [To Burst Out Laughing: Studies on Classical Chinese Jokes]. Taipei: Le Jin.

Liao, C.-C. 2001. Taiwanese Perceptions of Humor: A Sociolinguistic Perspective. Taipei: Crane.

Liao, C.-C. 2003a. "Taiwanese versus Japanese Sense of Humor". The National Chi Nan University Journal 6 (2): 83-112.

Liao, C.-C. 2003b. Jokes, Humor and Chinese People. Taipei: Crane.

Liao, C.-C. 2003c. "Humor versus Huaji”. Journal of Language and Linguistics 2 (1): 25-46.

Liu, T., T.Y. Chuk, S.-L. Yeh, and J.H. Hsiao. 2016. "Transfer or Perceptual Expertise: The Case of Simplified and Traditional Chinese Character Recognition”. Cognitive Science: A Multidisciplinary Journal 40 (8): 1941-1968.

Maurer, D., R. Le Grand, and C.J. Mondloch. 2002. "The Many Faces of Configural Processing”. Trends in Cognitive Sciences 6 (6): 255-260.

McCleery, J.P., L. Zhang, L. Ge, Z. Wang, E.M. Christiansen, K. Lee, and G.W. Cottrell. 2008. "The Roles of Visual Expertise and Visual Input in the Face Inversion Effect: Behavioral and Neurocomputational Evidence”. Vision Research 48 (5): 703-715.

Oring, E. 2003. Engaging Humor. Urbana-Champaign, IL: University of Illinois Press.

Rusk, B. 2007. "Old Scripts, New Actors: European Encounters with Chinese Writing, 1550-1700". East Asian Science, Technology, and Medicine 26: 68-116.

Shi, D., and W. Luo. 2013. Hànzì de Zhihuì [The Wisdom of Chinese Characters]. Beijing: Beijing Language and Culture University Press.

Shultz, T.R. 1976. "A Cognitive-Developmental Analysis of Humor". In Humor and Laughter: Theory, Research, and Applications, eds. A.J. Chapman and H.C. Foot. London: John Wiley and Sons, 11-36.

Suls, J. 1972. "A Two-Stage Model for the Appreciation of Jokes and Cartoons: An Information Processing Analysis". In The Psychology of Humor, eds. J. Goldstein and P. McGhee. New York, NY: Academic Press, 81-100.

Suls, J. 1983. “Cognitive Process in Humor Appreciation”. In Handbook of Humor Research, vol. 1, eds. P. McGhee and J. Goldstein. New York, NY: Springer Verlag, 39-57. 
Tang, L., and P. Yang. 2011. "Symbolic Power and the Internet: The Power of a 'Horse"'. Media, Culture and Society 33 (5): 675-691.

Tang, T.-C. 1989. "Xīncí Chuàngzào yŭ Hànyŭ Cífă" [The Creation of New Words and Chinese Morphology]. In Hànyǔ Cífă Jùfă Xùjí [Further Writings on Chinese Morphology and Syntax], ed. T.-C. Tang. Taipei: Student Book Company, 93-146.

Tong, L.-Y.C. 1999. Discourse Is Fun: A Linguistic Study of Xiangsheng. Taichung: Providence University MA Thesis.

Wei, B. 2014. "The Origin and Evolvement of Chinese Characters". Gdańsk Journal of East Asian Studies 5: 33-44.

Williams, C., and T. Bever. 2010. "Chinese Character Decoding: A Semantic Bias?". Reading and Writing: An Interdisciplinary Journal 23 (5): 589-605.

Yamaguchi, H. 1988. "How to Pull Strings with Words: Deceptive Violations in the Garden-Path Joke". Journal of Pragmatics 12 (3): 323-337.

Yang, L. 2017. "Platforms, Practices, and Politics: A Snapshot of Networked Fan Communities in China". In The Routledge Companion to Global Internet Histories, eds. G. Goggin and M. McLelland. New York, NY-London: Routledge, 370-383.

Yu, W.-C. 2014. "Hànyīng Wénzì de Yōumò Xiūcí Gōngnéng Qiăntàn" [A Survey on Chinese and English Writing Systems in the Delivery of Humor]. Yǔyán yŭ Fānyì 1: 5-13.

Yue, X.D. 2010. "Exploration of Chinese Humor: Historical Review, Empirical Findings, and Critical Reflections". Humor: International Journal of Humor Research 23 (3): 403-420.

Zhao, J.-F. 2014. "Qiăntán 'Jiǒng'-zi”" [A Brief Discussion on the Chinese Word “Jiǒng”]. Journal of Yuncheng University 32 (4): 84-86.

Zhou, Z. 2014. "The Six Principles of Chinese Writing and Their Application to Design as Design Idea". Studies in Literature and Language 8 (3): 84-88.

\section{INTERNET SOURCES}

WWW1. https://hk.appledaily.com/news/art/20100401/13884022 (March 3, 2021).

WWW2. https://en.wikipedia.org/wiki/Grass_Mud_Horse (March 3, 2021).

WWW3. https://archive.nytimes.com/www.nytimes.com/2009/03/12/world/asia/12beast.html (March 3, 2021). WWW4. https://m.facebook.com/Bikhim/photos/a.271199425686/10156795227580687/?type=3\&source $=48$

(November 14, 2019).

WWW5. https://www.mirrormedia.mg/story/20190409ent003/ (November 16, 2019). 


\section{Elementy humorystyczne w znakach chińskich - perspektywa społeczno-kulturowa i historyczna}

Słow a kluczowe: znaki chińskie, chińskie ligatury, homofoniczne gry słowne, zachowanie ludzkie, humor.

\section{STRESZCZENIE}

Celem artykułu jest ukazanie elementów humorystycznych zawartych w znakach chińskich w perspektywie społeczno-kulturowej i historycznej. Podjęta analiza opiera się na definicji śmiechu sformułowanej przez Bergsona ([1911] 2014) oraz dwóch funkcjach chińskiego humoru - 寓教於樂 tzw. 'zawieranie morału w rozrywce' (Liao 2001) oraz 會心微笑 tzw. 'szczery śmiech lub wymowny uśmiech' (L.-C. Chen 2017). Materiał badawczy wykorzystany w badaniu pochodzi z różnorodnych źródeł internetowych i literackich, oraz z repertuaru językowego autorów. Badanie pozwoliło na wyróżnienie sześciu źródeł humoru zawartego w znakach chińskich: (a) formy wizualne znaków; (b) dekompozycja znaków; (c) chińskie ligatury; (d) chińskie gry słów na bazie homofonów; (e) błędne odczytywania podobnych znaków; oraz (f) zapożyczenia z kanji - znaków chińskich używanych w języku japońskim. Wyniki pracy sugerują, że humorystyczność poszczególnych znaków wiąże się z posiadaniem ludzkich cech behawioralnych i ukrytych pouczeń, które to prowadzą do wywołania w odbiorcy będącego członkiem społeczności chińskojęzycznej 'szczerego śmiechu lub wymownego uśmiechu'. 